\title{
METHODS OF ATTRACTION AND RETENTION OF GENERATION Z STAFF
}

\author{
Irina Sidorcuka, ${ }^{1}$ Anna Chesnovicka ${ }^{2}$
}

\begin{abstract}
The contemporary job market is facing the arrival of new type of employee -generation $\mathrm{Z}$ representatives, known as "digital natives", who are described as technological, social, global and developed, the most connected, clever and educated generation thatever existed before, driven by social media, influenced by brands and musical culture. At the moment, this generation is considered to be two billion big. This study is looking at the existing methods of generation $\mathrm{Z}$ staff attraction and retention in the company Evolution (Latvia), where they make a majority. Further analyzing which of the methods are perceived as most efficient and which values of this generation are met by the company. Methods include company literature review, questionnaires and interviews. It was concluded the Gen $\mathrm{Z}$ have specific preferences in communication and can be reached through a variety of social platforms and special events provided by the company. As potential and current employees, they are not looking for life-long employment, put forward their specific values and expect the potential employer to attract them by meeting their needs in terms of flexible working hours, flexible (varied) jobs where their individuality can be applied, company excellent reputation, innovation, speed of change, platform for educational and promotional advancement, specific fringe benefits.
\end{abstract}

UDC Classification: 303; DOI: http://dx.doi.org/10.12955/cbup.v5.1030

Keywords: Generation Z, staff attraction, retention, employees 'values.

\section{Introduction}

Nowadays, attraction and retention of new staff is becoming more challenging because of the diversity of job roles needed on the one hand and the variety of new methods of attraction and technologies available on the other hand (Blacksmith and Poeppelman, 2014). Recruitment today is more strategic, personalized, and targeted than ever (Sunderberg, 2014). The main challenge for the companies remains finding and attracting new staff that would most successfully fit the company and would contribute to its further development. It is crucial to select right people since it has direct interconnection with the further success of a company on the market and deals with the competitiveness of an organization in general (Osoian and Zaharie, 2014).

The contemporary tendency on the job market, where the increasing number of potential recruits are representatives of generation $\mathrm{Z}$ calls for analysing the needs and expectations, values and interests of this potential workforce of the future, in order for the companies to be well equipped in meeting these values and expectations and, thus attracting and retaining the best candidates.

The purpose of this paper is to provide an overview of the existing methods of new staff attraction through recruitment procedures and retention policies, build the profile of the generation $\mathrm{Z}$ potential employee, analyze which of recruitment methods and company benefits are the most effective in attraction and retention of generation $\mathrm{Z}$.

The study comprises a literature review and empirical part carried out in the company: Evolution Gaming, the biggest employer in Latvia, where the majority of employees (81\% in 2016) are representatives of generation $\mathrm{Z}$.

\section{Literature review}

Both prosperity and survival of each organization strongly relies on the quality of human capital employed by the company. This is the reason why organizations should concentrate on attracting highly skilled and competitive candidates, which can be ensured by an efficient recruitment process (Muscalu, 2015). It is important for organization to understand that employees are intangible assets as their knowledge, skills and behavior can play an essential role. Organizations with professional and experienced employees have an enormous competitive advantage (Hawkins, 2007). The main objective of recruitment can be defined as attracting enough candidates that are responding to particular job requirements, so that the employer could choose and recruit the greatest individual to fill the vacancy (Muscalu, 2015).

According to Chand (2015) informing candidates about new vacancies available in the organization and attracting them are essential aspects of the recruitment and hiring process in which both internal and external resources can be exploited.

\footnotetext{
${ }^{1}$ RISEBA University, 3 Meza str., Riga, Latvia, irina.sidorcuka@ riseba.lv

${ }^{2}$ Senior Schedule Specialist, Evolution Latvia,151 Brivibas str., Riga, Latvia, Acesnovicka@evolutiongaming.com
} 
Internal recruitment strategy according to Applegate (2015) is usually implemented through promoting employees already working in organization.The following advantages of internal personnel selection for the vacant post were suggested (Reichard et al. 2014): time efficiency, improvement of loyalty and morale of employees, possibility to better estimate the abilities of the candidate, lower costs involved, motivation of other employees to aim at promotion, ease of contacting applicants.

However, in majority cases, organizations refer to external recruitment when there are no appropriate candidates able to fill the particular job position within company staff.Reichard et al. (2014) highlight the following advantaged of external recruitment for the companies (Reichard et al. 2014): possibility to invite fresh ideas and welcome innovation, provision of opportunities for unemployed, bigger number of applicants to choose from, possibility to bring new departmental insights.

Decenzo and Robins (2014) and Shamis (2015) identify the following methods of external recruitment: advertising through media(Internet, newspapers, radio and television);employment agencies; recruiters who usually are used in colleges and technical schools; special events when employees of the company are used to attract a big number or candidates for interviews;internship programmes placing a student in a seasonal or temporary positions for further employment;executive search firms services (headhunting); employee referral(when existing employees are offered to recommend names of individuals they believe would be the right ones for a vacant position, usually in return for a financial reward for such recommendation); unsolicited Walk-In applicants (applicants can be attracted by organizations with perfect reputation without any recruitment method being used).

Whatever methods the company chooses, it should address to the potential hires through the most efficient method taking into account the needs and values of the future employees. As hiring is not only a process of assessing potential candidates in terms of their suitability for the position, but rather an organization as a future employer is being assessed by an applicant (Mason, 2014).

In order to be successful in attracting a large pool of applicants, organizations need to understand their potential candidates looking at such factors as the candidate's values, motivation and attitude. Mason (2014) highlights that it is crucial to understand motivation of potential applicants as this is going to assist in choosing sourcing strategy and style of communication. Applicants might be employed by another organization holding the same position as the vacant one, or, vice versa they might occupy lower level position, however they are ready for promotion. It is worth considering values applicants may have related to both inside and outside the working place. Often, candidates are interested in the possibilities of a future promotion, advancing specific skills, gaining experience and positive feedback from their direct manager. Outside the working place applicants tend to value family life, communities, cultural activities, professional and social networks.

Armstrong (2006) advises analyzing recruitment strong and weak points from the very start, as this analysis can enhance employer's attractiveness for the potential candidate through building a special value proposition, thus becoming the "employer of choice." Barber (1998) suggests that the stage of hiring can be related to applicants' working preferences and decisions. And to ensure successful hiring, organizational attributes should fit candidate's individual employment values and critical indicators of employee satisfaction. Basically, organizational attributes include a perception of what the company provides in terms of working conditions and environment. Such aspect as advancement opportunities, fringe benefits and job security are positively appreciated by applicants when evaluating future employer, and influence organizational attractiveness (Robertson et al., 2005).

There are some tangible and intangible factors that attract candidates and motivate them to work for a certain organization, and to stay within it or vice versa drive them away (Regovich, 2014). Among the most widely acknowledged by Crossley and Jamieson (1997)and Regovich (2014) are the following factors that influence staff attraction and retention: pay and bonuses, the job itself (when employee get satisfaction through work),creative benefits and rewards,fun and safe working environment, cooperative and helpful colleagues, the organization's brilliant reputation and corporate success, and understanding managers.

Fringe benefits offered by companies have a powerful influence on employee satisfaction. According to the survey of annual trends performed by Andruss (2012) $49 \%$ of employed respondents noted that benefits were a significant motive when they started working for a certain company, while $60 \%$ responded that benefits are a significant reason for remaining within an organization. There is avariety 
of different fringe benefits offered by contemporary employers, starting with snacks and free drinks, to a retirement plan (Horton, 2014). Dishman (2016) highlighted the most important benefits valued by employees: health care insurance (e.g., medical, dental) 40\%,vacation/paid time off 37\%, performance bonus $35 \%$,paid sick days $32 \%$, and retirement plan and/or pension $31 \%$.

\section{Z Generation Characteristics}

Generations are built of people who were born during a certain period of time and who were exposed to the same events, have been impacted by similar technologies and spend their lives under equitable conditions (McCrindle, 2015). According to Burrus (2016), every generation is most likely to form different needs, aspirations and wants accordingly to the various periods of their lives when their responsibilities and tasks change. Generation $\mathrm{Z}$ can be described as technological, social, global and developed. They are called the most connected, clever and educated generation ever existed before, who have adopted technological developments, are driven by social media, influenced by brands and musical culture. At the moment, this generation is considered to be two billion big and according to McCrindle (2015), they are not only introducing the future, they are constructing it.There are different thoughts concerning the exact time period when Generation Z starts and ends however, the majority of experts agree individuals born from the mid-90s till 2004 belong to the generation (Mueller, 2015). The childhood of Gen $\mathrm{Z}$ was spent during the economic crisis and periods of terrorism and climate change. There is an opinion that this generation is about to spend their youth and adult years in an era of economic and social renewal. Moreover, they are observers of changes in different household structures. Today they are students and college graduates, nevertheless tomorrow they will become employees of the big organizations, clients and consumers (McCrindle, 2015).Generation Z sometimes is called "digital natives" because of their ability to feel comfortable with ICT.People from Generation $\mathrm{Z}$ were born after the Internet and mobile phones were invented, so they do not know life without having those innovations accessible when only there is a need for them. They spend a lot of time online, communicating with their friends, or sometimes with virtual strangers, they are not afraid of sharing personal information in different social medias (Bernstein, 2015).

This generation is considered to experience unique stimuli in their lives, starting with the Global Financial Crisis, continued by growing cultural diversity, the spread of worldwide known brands, and acceleration of communication in social media. As McCrindle (2015) assures, this generation will live longer lives, and they will most likely change jobs and work in different organizations than any generation before them. Mueller (2015) notes that this generation is able to grasp and create innovations in technology quicker than predecessors. Generation $\mathrm{Z}$ has witnessed a lot of difficult moments during their childhood years: parents losing jobs, sold family homes because of crisis, war and social argues across the world. They do understand that hard work is needed to gain money and live in peace(Harris, 2016).

Gen $\mathrm{Z}$ usually are ready to express their opinions, it is significant to respect them and assist, to emphasize their energy and creativity. Companies, that will meet all needs of this generation, will benefit from their hard work, continuous engagement and brilliant ideas in the nearest future (Half, 2015).It is predicted that Generation $\mathrm{Z}$ is about to change workplaces with their different attitudes, perceptions and styles as soon as they will enter workforce (Mueller, 2015) like Millennials or Generation Y, born 1977 - 1994 (Harris, 2016). Generation Z are used to immediate access to information and are sure that everything can be found on the internet, similarly to their older Gen $Y$ representatives, they are unstoppably engaged in the processing of information. Like Millennials, they prefer to deal with their problems independently, and before asking for advice or help will search for solution on YouTube or other platforms of video tutorials (Biro, 2015), Mueller (2015) assures, that Generation $\mathrm{Z}$ are born multitaskers which is an advantage. However,McCrindle, (2015) argues that at the moment they are completing many tasks at once, their attention is divided by particular tasks, so it may result in loosing ability to concentrate so generation requires more time to analyze complex information. It was also stated by McCrindle (2015), that sometimes for them speed matters, not accuracy.

Generation $\mathrm{Z}$ at the working place

In 2017 the eldest representatives of Generation $Z$ will turn 22-23, so a large part of them are still not employed however, in the nearest future the situation will change dramatically, by the year 2020 they 
are going to comprise 1 in 5 employees. Due to ageing population in Europe, this generation will start their careers in times where the supply of employees is reducing. Workforce shortage will take place since there will be fewer people entering the working force than exiting it. The optimistic point is that the younger generation is going to possess a high level of education however, due to issues arising in the employment sector described above, it is the Generation $\mathrm{Z}$ workforce that is going to be in demand, rather than jobs (McCrindle, 2015)

Generation Z's entrance in the workforce will bring some changes for recruiters. They shall be ready to advertise and engage potential employees on a wide range of different platforms on an everyday basis. Companies will have to understand that it is important to be as connected as Generation $\mathrm{Z}$ is if they are willing to recruit young talents. Organizations will need to follow up to their favorite networks, and companies will require to be honest and transparent concerning things they say and promise, as Generation $\mathrm{Z}$ tend to be skeptical of marketing (Biro, 2015).

Apart from the need to be connected Generation $\mathrm{Z}$ is mostly looking for temporary rather than longterm permanent or even life-long employment as the previous generations(O'Malley,2006), they are not expected to stay working for the same company for more than a few years.

Flexible schedules will be even more popular as they are nowadays because of preferences of Generation Z to move farther away from classic 9-to-5 hours spent in the office. As Biro (2015) notes, this generation will be able to separate working time and life. As it was told by Baumann (Baumann, 2014) on average, the young generation is planning to be employed by four companies during their lifetime. It can be explained by their willingness to gain robust work experience, which can be obtained from one or two companies, nevertheless this will be reached from working at different organizations.

Generation $\mathrm{Z}$ as employees of the future will consider it is important to have life/work balance, trust, flexibility, engagement, fresh ideas, amusement, creativity, and global working atmosphere (McCrindle, 2015). They will appreciate recognition for their efforts, which can be explained by their children years spent in safety and support at home, in public and during their education. That is a reason why they believe support will continue to be around, even at the working place. For nowadays workers it is crucial to have a variety of needs met at work, for Generation $\mathrm{Z}$ it more about social connection, experience, education, knowledge, and even environmental sustainability. As McCrindle (2015) notes, this generation is not so much motivated by remuneration as they are by other benefits.

When searching to attract and maintain Gen Z, the employers should take into account that they value ownership and individuality at the working place. Motivation comprises task variety and creativity, while it is the internet that has influence over profession selection. According to Stone et al.(2015) Millennials as employees prefer more interactive, interpersonal, information-rich approaches to all of the areas of HR management.They tend to prefer an interactive training style. They believe the most effective leadership style can be reached through consensus, they are influenced by global and shortterm desires. They are expressing their ideas freely and boldly when it comes to management (McCrindle, 2015).

\section{Research process, methodology and design}

The research was conducted in the company Evolution Gamingwhich is a leading B2B provider of Live Casino systems in Europe. The group today employs approximately 1,800 people of whom a majority are based in Latvia and Malta. The parent company is domiciled in Sweden. (Evolution Gaming Group, 2016).At the moment, there are 1,300 employees working in Riga Offices, mostly holding position of Game Presenters or IT specialists. In 2017 Evolution Gaming is planning to expand and to offer 600 new job positions.According to LETA (2015) the CEO of a company SvanteLiljeval announced at annual Nordic-Baltic business forum that Evolution Latvia will continue investing in its employees, infrastructure and offices, increasing its office space to 7000 square meters.

As the requirements for the staff are specific and the level of demand is high in terms of skills and competencies (advanced English language competence, stress resistance, artistic and presentation skills, etc.) and the staff turnover is high (approximately $30 \%$ per annum), the company is actively working on finding the most effective methods of staff attraction and retention(Evolution Gaming Group, 2016) 
The initial aim of the research was to evaluate the existing recruitment practices and to identify the most effective ways how to attract Generation $\mathrm{Z}$ staff. To evaluate perception of the company by the young generation and investigate whether Evolution Latvia addresses the values of their existing working force through offering motivation benefits.

The data were collected through questionnaires and interviews with the current staff as well as from the company documentation. The sample for the questionnaire comprised 210current employees of Evolution Latvia, the age group from $18-21$, making $58 \%$ or 121 respondents, $23 \%$ of respondents in the group from 22-24. The questionnaire was based on graded answers (from 1- least preferred to 5most appreciated) to the questions regarding the most effective methods of advertising posts, factors influencing attractiveness of the employer, preferred benefits offered, and possible reasons to leave the company. The author calculated the average score of each characteristic by combining the responses of the 210 respondents.

\section{Findings}

Sources and methods of job advertising

Among a wide variety of sources of job advertising used by the company at present Generation Z respondents gave preference to word-of-mouth advertising $(4,9)$ as the most noticeable and effective one. The second and the third most effective methods appeared to be the same as for older than 23 employees - Social Media $(4,8)$, however youngsters tend to notice adverts there more often compared to the group aged 23 and more $(4,2)$. Advertising in Cafes, Restaurants and Cinemas is the third most noticeable $(4,6)$. Both age groups found that Newspapers \& Magazines $(2,5$ and 2,2), TV $(2,6$ and 2,3), Billboards $(2,7$ and 2,6) are less effective sources of advertising, that are often being ignored by Generation Z (18-22), and those older than 23. In the interviews it was highlighted that employee referrals and special events organized by the company at schools, colleges and campaigns in social networks are most effective, e.g. Virtual Career Days with www.draugiem.lv, www.delfi.lv,www.cv.lv, using Facebook and Instagram accounts, and aYouTube channel, where they run number of campaigns and competitions. Advertising campaigns were considered more successful if combined with attracting celebrities and brands (e.g.now the company has come out externally in cooperation with Reebok Latvia), supporting a healthy lifestyle, positioning itself as being young and dynamic (Figure 1).

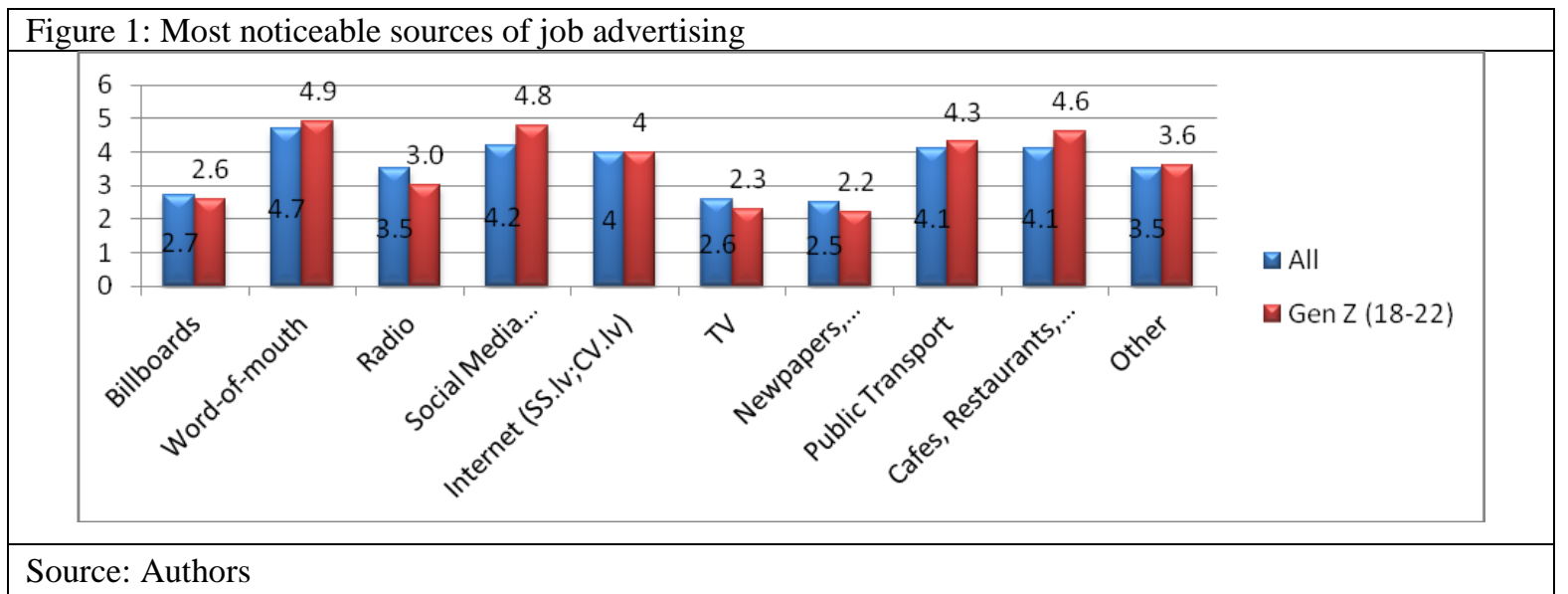

Factors of employer's attractiveness to staff

The most highly valued factors of employer's attractiveness were:pay $(4,5)$, the job itself $(4,3)$, and benefits and working environment equally $(4,2)$, whereas less important stated were training \& development $(3,3)$, new contacts $(3,7)$, and location/position of the office $(3,8)$. However, for the youngest representatives flexible schedule was the most important factor $(4,7)$, followed by the job itself $(4,6)$ which they described as exciting, interactive, communicative and using advanced IT. The corporate image was the third most important factor $(4,5)$. The company's growth, dynamism, international environment were highlighted. Respectively, the less important elements stated were new contacts $(3,5)$, location/position of the office $(3,6)$ and pay $(3,7)$. Nevertheless, Generation $Z$ considers benefits offered by the company $(4,4)$, and training \&development $(4,2)$ to be significant (Figure 2 ). 


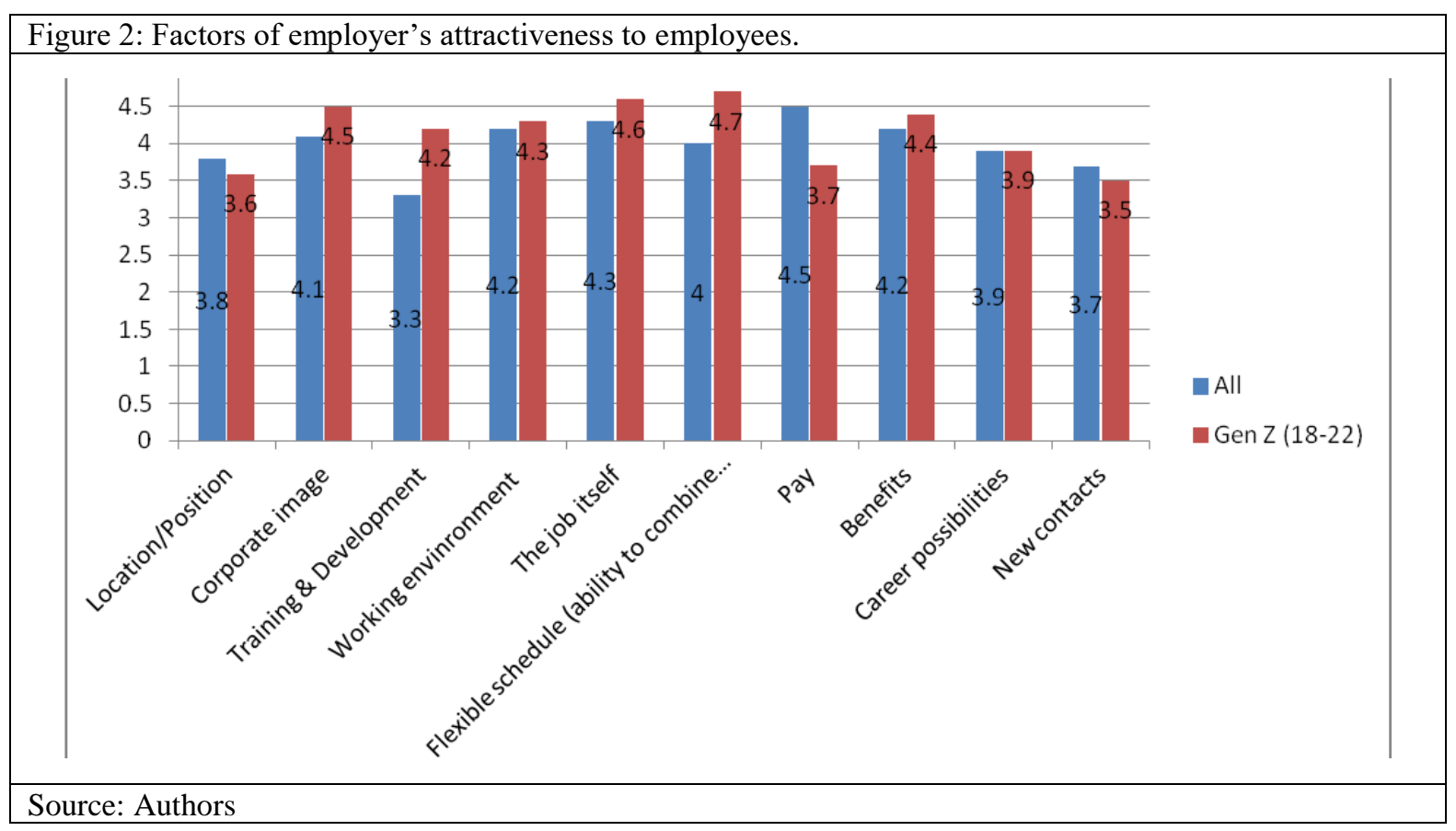

Meeting the values of staff

The majority of respondents evaluated flexible schedule $(4,8)$ to be the value of young generation the company is most likely meeting. It is followed by innovation $(4,6)$ and promotion possibilities $(4,5)$. According to the responses of Game Presenters, Evolution Latvia is less successful in meeting such values as ability to show individualism $(3,4)$, trust $(3,6)$, and life work balance $(3,9)$ (Figure 3$)$.

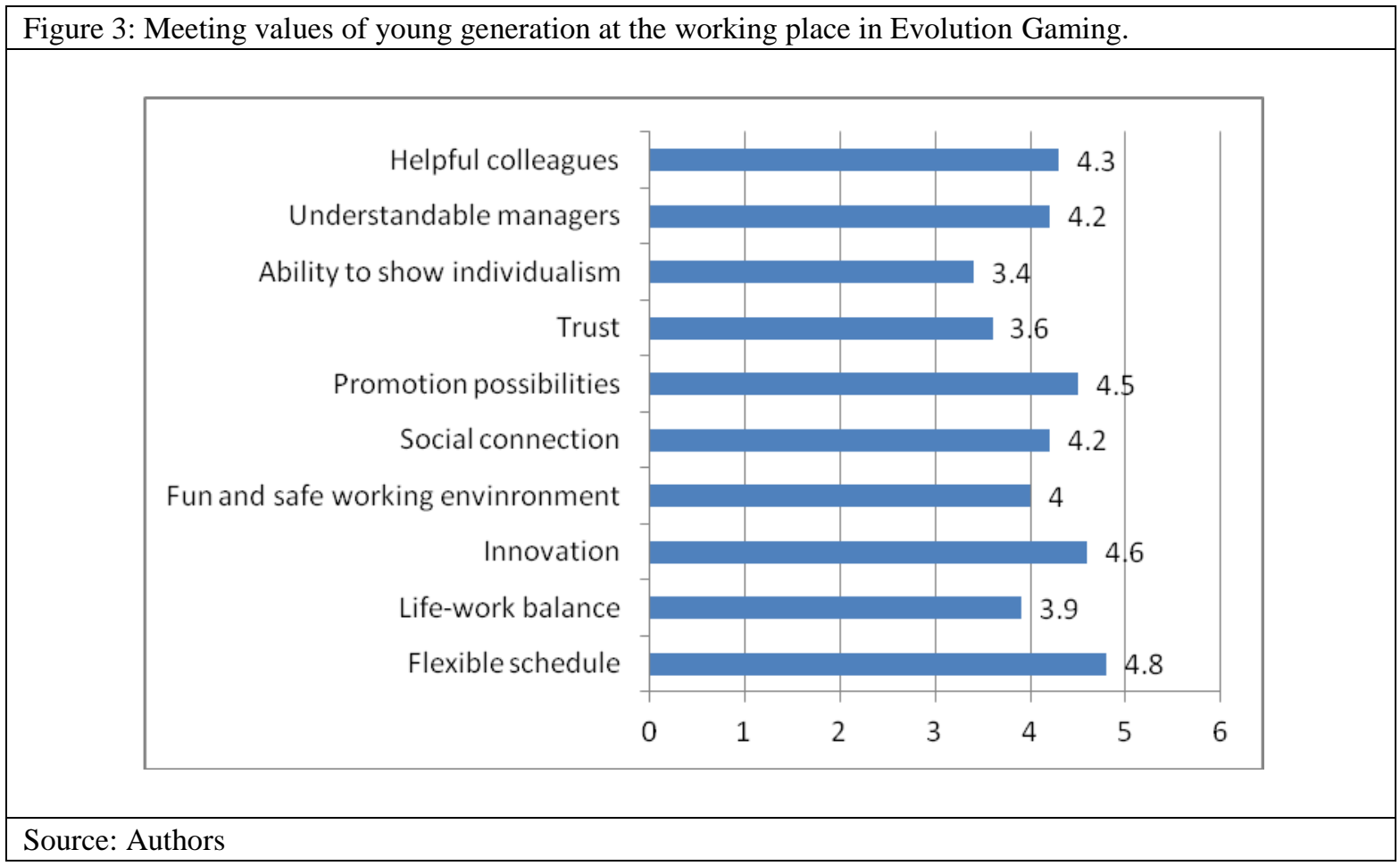

Fringe benefits offered by Evolution Latvia

The most important to respondents benefit currently offered by Evolution Latvia is the gym $(4,8)$ showing that the young generation is supporting a healthy lifestyle, it is followed by paid vacation $(4,7)$ and health insurance $(4,6) .25 \%$ or 53 people would appreciate to have free parking, a paid day off on a Birthday was supported by $23 \%$ of respondents, while $20 \%$ would like to have more free sports events itis closely followed by free healthy food that was chosen by $19 \%$.Special offers for SPA 
services would be the most desired fringe benefit for $8 \%$. 5\% of respondents falling into "other" category, have stated that they would like to see different development classes organized, free cinema tickets, language courses, etc.

Turnover and reasons to leave Evolution Latvia

$42 \%$ of respondents or 87 people are planning to stay in work from 6 months till one year, that indicates that they tend to consider short term employment. $25 \%$ of respondents would work in the Company from 1 year till less than 3 years. $23 \%$ current Game Presenters are planning to exit in 6 months long period. Only $8 \%$ showed willingness to remain at Game Presenter position for 3 years till 5 years, and only $8 \%$ of respondents are eager to work for 5 years or more. The potential reason to exit the company is unwillingness to work long for one company (28\%), followed equally ( $23 \%$ each) by moving to jobs related to an improved level of education/qualification and desire to gain new experience. $13 \%$ have chosen burn-out of Game Presenter's position, $8 \%$ lack of innovation.

\section{Research limitations}

The study was limited by the specifics of the jobs profile in the company Evolution, and to get a wider view on the attraction and recruitment of generation $\mathrm{Z}$ a study should be proceeded in a number of companies in different sectors of economics among representatives of a wider variety of jobs. Another limitation is specific personal values of each individual which may differ from the generalized values of generation $\mathrm{Z}$.

\section{Conclusion}

The most powerful method in attracting new recruits ,the company Evolution is currently using, wordof-mouth with employee referrals, a continuous presence in majority of popular media platforms, attraction of famous brands to cooperate(Reebok Latvia), facilitation of sports and social events, and promotion in schools and universities.

The most important attributes of employer's attractiveness appeared to be flexible schedule allowing to combine work and studies; the job itself which is interactive, varied, communicative, exciting, connected with new IT; and a corporate image of the company as famous, growing, dynamic.

Generation $\mathrm{Z}$ values, successfully met by the company, are flexible work hours, innovation and the possibility of growth(Evolution Academy).Evolution Latvia is less successful in meeting such values as the ability to show individualism, development of trust and provision of life work- balance.

The most important benefit for Gen Z currently offered by Evolution Latvia is gym facilities showing that the young generation is supporting a healthy lifestyle, it is followed by paid vacation and health insurance. Nevertheless,the majority expressed a wish to have more possibilities for sports, social events, paid day-off for birthdays.

The majority of Gen $\mathrm{Z}$ staff have short-term desires and are not planning long-term employment in one company, they are ready to leave their current employer in search for better opportunities, innovation, novelty. This lack of loyalty to their present employer and fast changing priorities of Gen $\mathrm{Z}$ require permanent adaptation to their needs and values, active permanent communication, quick reaction to change and continuous innovation in the companies.

\section{References}

Andruss, P. (2012). How to Attract -- And Retain -- Staff When You Can't Pay Big Bucks. [ONLINE] Available at: http://www.entrepreneur.com/article/223516. [Accessed 18 March 16].

Applegate M.(2015). Difference Between the Internal \& External Recruitment Strategies. [ONLINE] Available at : http://smallbusiness.chron.com/difference-between-internal-external-recruitment-strategies-25708.html[Accessed 18 March 16].

Armstrong, M., (2006). A Handbook of Human Resource Management Practice. 5th ed. London and Philadelphia: Kogan Page.

Barber, A. (1998). Recruiting employees: Individual and organizational perspectives. Thousand Oaks, CA: Sage Publications.

Bernstein,R. (2015).Move Over Millennials - Here Comes Gen Z.[ONLINE] Available at :http://adage.com/article/cmostrategy/move-millennials-gen-z/296577/. [Accessed 25 March 16].

Biro, M.M. (2015). What Gen Z's Arrival In The Workforce Means For Recruiters. [ONLINE] Available at: http://www.digitalistmag.com/future-of-work/2015/10/05/what-gen-z-arrival-means-for-recruiters-03509530. [Accessed 18 March 16]. 
Blacksmith, N., Poeppelman, T (2014). 'Three Ways Social Media and Technology Have Changed Recruitment', TIP: The Industrial-Organizational Psychologist, 52, 1, pp. 114-121, Academic Search Complete, EBSCOhost, viewed 22 December 2015.

Burrus. D. (2016). Gen Z Will Change Your World Again. Available at: http://www.huffingtonpost.com/daniel-burrus/gen-Zwill-change-your-wo_b_9150214.html. [Accessed 20 March 16].

Chand, S. (2015). Sources of Recruitment of Employees: Internal and External Sources | Recruitment. Available at: http://www.yourarticlelibrary.com/recruitment/sources-of-recruitment-of-employees-internal-and-external-sourcesrecruitment/25954/. [Accessed 20 March 16].

Crossley, J. C. and Jamieson, L. M. (1997). Introduction to Commercial and Entrepreneurial Recreational. Champaign, IL :Sagamore Publishing

Decenzo, D.A., RobinsP.S.(2014). Sources of Recruitment.

Availableat:http://www.zeepedia.com/read.php?sources_of_recruitment_alternatives_to_recruitment_quantity_of_the_applic ants_quality_of_the_applicants_human_resource_management $\& b=33 \& c=17$. [Accessed 20 March 16].

Dishman, L. (2016). These Are The Best Employee Benefits And Perks. [ONLINE] Available at:

http://www.fastcompany.com/3056205/the-future-of-work/these-are-the-best-employee-benefits-and-perks. [Accessed 23 March 16].

Evolution Gaming Group. 2016. Year-end report | January - December 2015| . [ONLINE] Available at:https://www.evolutiongaming.com/sites/default/files/477485.pdf. [Accessed 28 March 16].

Half, R. (2015). Get ready for Z Generation. [ONLINE] Available

at:https://www.roberthalf.com/sites/default/files/Media_Root/images/rh-pdfs/rh_0715_wp_genz_nam_eng_sec.pdf. [Accessed 20 March 16].

Harris, J. (2016). Baby Boomers to Generation Z what's in store for the workplace in 2016?. [ONLINE] Available at: https://www.linkedin.com/pulse/baby-boomers-generation-z-whats-store-workplace-2016-james-harris. [Accessed 20 March 16].

Hawkins, M. (2007). Alpinelink. [ONLINE] Available at: http://www.alpinelink.com/Docs/Employees_Are_Assets.pdf. [Accessed 27 December 15].

Horton,M. (2014 ). What are some examples of common fringe benefits?. [ONLINE] Available at: http://www.investopedia.com/ask/answers/011915/what-are-some-examples-common-fringe-benefits.asp. [Accessed 25 March 16].

LETA. 2015. 'Evolution Gaming' nākamgadplānopieṇemtdarbā 600 jaunusdarbiniekus. [ONLINE] Available at: http://www.delfi.lv/bizness/uznemumi/evolution-gaming-nakamgad-plano-pienemt-darba-600-jaunusdarbiniekus.d?id=46701873. [Accessed 22 December 15].

Mason, H. (2014). Attracting candidates. [ONLINE] Available at: http://www.otago.ac.nz/humanresources/toolkit/recruiting/attracting-candidates/. [Accessed 23 March 16]

McCrindle, M. (2015). Generation Z Digital. [ONLINE] Available at: http://generationz.com.au/digital/. [Accessed 20 March $16]$.

Muscalu, E (2015). 'Sources of human resources recruitment organization', RevistaAcademieiFortelorTerestre, 20, 3, pp. 351359, Academic Search Complete, EBSCOhost, viewed 18 March 2016.

Mueller, J.(2015). Generation Z Characteristics. [ONLINE] Available at: http://www.ehow.com/info_8056211_generationcharacteristics.html. [Accessed 20 March 16].

O'Malley, S (2006), 'Attracting and Retaining Generation Y Employees', Insurance Advocate, 117, 24, p. 27, MasterFILE Premier, EBSCOhost, viewed 27 December 2015.

Osoian, C.,Zaharie, M (2014). 'Recruitment for competencies in public and private sectors', Transylvanian Review Of Administrative Sciences, 41E, pp. 129-145, Academic Search Complete, EBSCOhost, viewed 22 December 2015.

Regovich, D. (2014). Benefits that Attract and Retain Employees. Available at: http://www.plasticsbusinessmag.com/stories/082415/benefits-attract-retain-employees.shtml\#.VuwXN9KLTIU. [Accessed 18 March 16]

Reichard, C., Siegel, J., Wagner, D.(2014). Human Resource Management. Available at: http://www.slideshare.net/maiwandtasal/human-resource-management-46044404. [Accessed 22 March 16].

Robertson, Q., Collins, C., Oreg, S. (2005). The effects of recruitment message specificity on applicant attraction to organizations. Journal of Business and Psychology, 19, 319-339.

Shamis, B.(2015). Employee Recruiting Sources. Available at: http://selectingwinners.com/employee-recruiting-sources/. [Accessed 22 March 16].

Stone, D, Deadrick, D, Lukaszewski, K, \& Johnson, R (2015). 'The influence of technology on the future of human resource management', Human Resource Management Review, 25, 2, p. 216, MasterFILE Premier, EBSCOhost, viewed 27 December 2015.

Sunderberg, J. (2014). How LinkedIn has changed recruitment in the UK. The Under- The Industrial Organizational Psychologist 121 coverRecruiter.com. Retrieved from: http://theundercoverrecruiter.com/ linkedin-changed-recruitment-uk/ 